\title{
Clostridium coccoides, a New Species from the Feces of Mice
}

\author{
CHOJI KANEUCHI, YOSHIMI BENNO, AND TOMOTARI MITSUOKA \\ The Institute of Physical and Chemical Research, Wako, Saitama, 351, Japan
}

\begin{abstract}
Clostridium coccoides sp. nov. is described on the basis of 12 strains isolated from a number of fecal specimens from mice fed a high-lactose diet. The isolates are obligately anaerobic, gram-positive, sporeforming, nonmotile, coccobacillary to rod-shaped cells which occur singly, in pairs, and sometimes in chains. They differ from other clostridia principally in morphology; the nearly spherical form of the cells, particularly on agar media, is rather distinctive. The guanine plus cytosine $(\mathrm{G}+\mathrm{C})$ contents of the deoxyribonucleic acids of the new strains are 43 to $45 \mathrm{~mol} \%$, values similar to those of clostridia with high $\mathrm{G}+\mathrm{C}$ contents, such as Clostridium sphenoides, C. oroticum, C. indolis, C. innocuum, C. barkeri, and $C$. nexile; however, $C$. coccoides can be clearly differentiated from these organisms by numerous biochemical characteristics and/or fermentation products. The type strain of $C$. coccoides is CLC-1 (= ATCC $29236=$ NCTC 11035).
\end{abstract}

During studies on the effects of various diets on the intestinal flora of mice, a number of clostridia with an unusual coccoid to ovoid morphology were encountered. The strains differed sufficiently from other clostridia in morphology and/or guanine plus cytosine $(\mathrm{G}+\mathrm{C})$ content to suggest that they might belong to a new species. A study was undertaken, therefore, to determine the systematic position of these strains.

\section{MATERIALS AND METHODS}

Bacterial strains. Eighteen strains were studied. Twelve of these were isolated from the feces of mice fed cow's milk or a lactose-rich diet for a period of more than 3 weeks. Six strains, Clostridium indolis ATCC $25771, C$. innocuum ATCC 14501, $C$, nexile ATCC 27757 (4), C. oroticum ATCC 13619, C. sphenoides ATCC 19403, and Bacteroides clostridiiformis ATCC 25537, were obtained from the American Type Culture Collection, Rockville, Md., and all had high $\mathrm{G}+\mathrm{C}$ contents, relative to the genus Clostridium, as did the new isolates. $B$. clostridiiformis has been transferred to the genus Clostridium because of its sporeforming ability $(3,6,12)$, and it was included in this study for that reason.

Isolation and maintenance of cultures. Fecal materials emulsified in an anaerobic buffer solution were plated out on modified Eggerth-Gagnon (EG) agar (10), glucose blood liver (BL) agar (10), and Medium 10 agar (1). EG and BL agar plates were incubated at $37^{\circ} \mathrm{C}$ in an anaerobic steel-wool jar (11) filled with an atmosphere of $100 \% \mathrm{CO}_{2}$. Medium 10 was prepared "plate-in-bottle" fashion (9) and incubated at $37^{\circ} \mathrm{C}$. After incubation for 3 to 5 days, relatively large, yellowish-gray colonies were picked onto EG agar. Strains were maintained on prereduced EG liver slants with $\mathrm{H}_{2} \mathrm{CO}_{3}-\mathrm{CO}_{2}$ buffer (10) and stored at $4^{\circ} \mathrm{C}$. New transfers were usually made at 3-month intervals.
Cultural and biochemical tests. The methods for the cultural and biochemical characterization of the strains used in this study were described previously (6). The orotic acid hydrolysis was determined by the method of Wachsman and Barker (14).

Spore-formation test. For detection of spores, the method of Holdeman and Moore (2) was used. Spores were detected by observing them in stained preparations (Gram stain or spore stain) and by demonstrating the heat resistance of cultures. Organisms were cultivated on the surface of chopped meat (CM) (2) agar slants at $30^{\circ} \mathrm{C}$ and stained periodically for up to 2 weeks. They were also incubated on EG agar plates at $30^{\circ} \mathrm{C}$ for 7 days. Prereduced starch broth (2) was inoculated with growth from the CM agar slants, incubated for 7 days, and heated at 50,60, 70, and $80^{\circ} \mathrm{C}$ for $10 \mathrm{~min}$ in a water bath.

Fermentation products. Strains were grown for 2 days in peptone-yeast extract-Fildes-glucose (PYFG) broth (6). Alcohols, volatile acids, and non-volatile acids were analyzed for the most part by the method of Holdeman and Moore (2). Nonvolatile acids were methylated with diazomethane. Formic acid could not be detected by the method used.

DNA base composition. The $\mathrm{G}+\mathrm{C} \mathrm{mol} \%$ of the deoxyribonucleic acid (DNA) was determined by using the methods of Marmur (7) and Marmur and Doty (8). DNA from calf thymus (Worthington Biochemicals Corp., Freehold, N.J.) was included in each set of analyses as a standard; the $\mathrm{G}+\mathrm{C}$ ratio of the calf thymus was regarded as $42 \mathrm{~mol} \%$.

\section{RESULTS AND DISCUSSION}

Description of the 12 new isolates: morphology. Obligately anaerobic, nonmotile, sporeforming, gram-positive coccobacilli to rods, occurring singly, mostly in pairs, and sometimes in short chains (Fig. 1). After incubation for 2 days, cells grown on EG agar were 0.6 to 1.0 by 0.6 to $1.3 \mu \mathrm{m}$. They were considerably elongated ( 0.8 to $1.5 \mu \mathrm{m}$ in length) in PYFG broth 


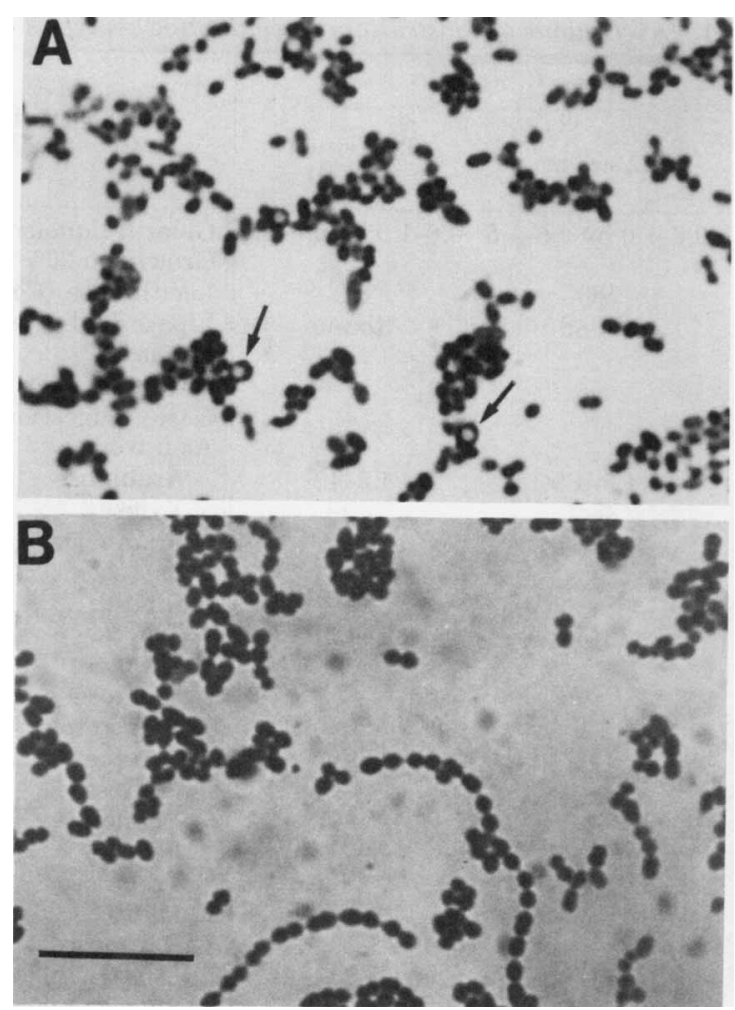

FIG. 1. Photomicrographs of gram-stained cells of Clostridium coccoides ATCC 29236, the type strain. (A) Cells from a 48-h-old EG agar plate; $(B)$ cells from a 7-day-old EG agar plate. Spores are indicated by arrows. Bar represents $10 \mu \mathrm{m}$.

and formed relatively long chains. Round, central to slightly subterminal spores $(0.8 \mu \mathrm{m}$ in diameter) were seen on CM agar slants (2) and EG agar plates after incubation for 3 to 5 days but were not consistently seen on BL agar plates. Cells bearing spores were usually distended and sometimes stained deeply by Gram stain.

After incubation for 2 days, surface colonies on EG agar were 1.5 to $2.5 \mathrm{~mm}$ in diameter, circular, convex, entire, smooth, translucent, shiny, yellowish-gray, and nonhemolytic. On BL agar, they became slightly larger in size, convex to umbonate, and opaque and yellowishwhite in the center with a translucent, gray margin.

Cultural and biochemical characteristics (Table 1). There was slight to moderate growth in PYF broth. PYFG cultures had abundant growth with smooth sediment, sometimes without turbidity, and a pH of 4.5 to 4.9 in 7 days. Growth in PYFG broth was enhanced by the addition of $10 \%$ rumen fluid but was not affected by the addition of $0.1 \%$ Tween 80 or both $0.0005 \%$ hemin and $0.00005 \%$ menadione. Bile
(20\%) was slightly inhibitory for growth. When grown in PYFG broth with added antibiotics, the strains were susceptible to penicillin ( 15 $\mu \mathrm{g} / \mathrm{ml})$ and rifampin $(15 \mu \mathrm{g} / \mathrm{ml})$, resistant to polymyxin $(10 \mu \mathrm{g} / \mathrm{ml})$, colistin $(10 \mu \mathrm{g} / \mathrm{ml})$, bacitracin $(3 \mathrm{U} / \mathrm{ml})$, and kanamycin $(1,000 \mu \mathrm{g} / \mathrm{ml})$, and tolerant to $0.001 \%$ brilliant green. The temperature for optimal growth was $37^{\circ} \mathrm{C}$. The strains usually grew well at 25 and $45^{\circ} \mathrm{C}$ but weakly at $15^{\circ} \mathrm{C}$. All strains resisted heating at $70^{\circ} \mathrm{C}$ for $10 \mathrm{~min}$, but they were variable in their resistance to $80^{\circ} \mathrm{C}$ for $10 \mathrm{~min}$ after incubation for 4 days at $30^{\circ} \mathrm{C}$ on $\mathrm{CM}$ agar slants and/or EG agar plates.

Acid was produced from arabinose, xylose, rhamnose, sorbose, ribose, glucose, mannose, fructose, galactose, sucrose, maltose, cellobiose, lactose, trehalose, melibiose, raffinose, melezitose, dulcitol, mannitol, sorbitol, inositol, salicin, amygdalin, $\alpha$-methylglucoside, and $\alpha$-methylmannoside. Esculin, starch, and glycerol were fermented weakly. Dextrin, glycogen, inulin, and erythritol were not fermented. Starch and orotic acid were not hydrolyzed. All of the strains hydrolyzed esculin. 
TABLE 1. Descriptions of Clostridium coccoides and its type strain ${ }^{a}$

\begin{tabular}{|c|c|c|c|c|c|}
\hline \multirow[b]{2}{*}{ Characteristics } & \multicolumn{2}{|c|}{ C. coccoides } & \multirow[b]{2}{*}{$\begin{array}{l}\text { Characteristics } \\
\text { (continued) }\end{array}$} & \multicolumn{2}{|c|}{ C. coccoides } \\
\hline & 12 strains & $\begin{array}{l}\text { Type strain } \\
\text { (CLC-1) }\end{array}$ & & $\begin{array}{c}12 \\
\text { strains }\end{array}$ & $\begin{array}{c}\text { Type } \\
\text { strain } \\
\text { (CLC-1) }\end{array}$ \\
\hline Cell size $(\mu \mathrm{m})$ & $0.6-1.0$ by $0.6-1.5$ & $0.6-1.0$ by $0.6-1.5$ & Gelatin liquefaction & - & - \\
\hline Spore: & & & Growth in $20 \%$ bile & $\mathbf{w}$ & w \\
\hline Location & $\mathrm{SC}$ & $\mathrm{SC}$ & Lecithinase (EYA) & - & - \\
\hline Shape & Round & Round & Lipase (tributyrin) & - & - \\
\hline Heat resistance at: & & & Urease & - & - \\
\hline $70^{\circ} \mathrm{C}$ for $10 \mathrm{~min}$ & + & + & Catalase & - & - \\
\hline $80^{\circ} \mathrm{C}$ for $10 \mathrm{~min}$ & $\mathbf{v}$ & + & Casein digestion & - & - \\
\hline Motility & - & - & Acid from: & & \\
\hline Final pH in PYFG & $4.5-4.9$ & $4.5-4.6$ & Arabinose & + & + \\
\hline Growth at: & & & Xylose & + & + \\
\hline $15^{\circ} \mathrm{C}$ & $\mathbf{w}$ & $\mathbf{w}$ & Rhamnose & + & + \\
\hline $25^{\circ} \mathrm{C}$ & + & + & Sorbose & + & + \\
\hline $45^{\circ} \mathrm{C}$ & + & + & Ribose & + & + \\
\hline \multirow{2}{*}{$\begin{array}{l}\mathrm{G}+\mathrm{C} \text { content of DNA } \\
(\mathrm{mol} \%)\end{array}$} & $43-45^{b}$ & 44.3 & Glucose & + & + \\
\hline & & & Mannose & + & + \\
\hline Products from PYFG & & & Fructose & + & + \\
\hline Alcohols & $\cdot$ & - & Galactose & + & + \\
\hline Acetic acid & $(+)$ & $(+)$ & Sucrose & + & + \\
\hline Propionic acid & - & - & Maltose & + & + \\
\hline Butyric acid & - & - & Cellobiose & + & + \\
\hline Lactic acid & - & - & Lactose & + & + \\
\hline Succinic acid & ++ & ++ & Trehalose & + & + \\
\hline Threonine conversion & - & - & Melibiose & + & + \\
\hline \multirow{2}{*}{$\begin{array}{l}\text { Lactate utilization to } \\
\text { propionic acid }\end{array}$} & - & - & Raffinose & + & + \\
\hline & & & Dextrin & - & - \\
\hline \multirow{2}{*}{$\begin{array}{l}\text { Glutamic acid decarbox- } \\
\text { ylase }\end{array}$} & - & - & Starch & $\mathbf{w}$ & $\mathbf{w}$ \\
\hline & & & Glycogen & - & - \\
\hline Nitrate & - & - & Inúlin & - & - \\
\hline Indole & - & - & Glycerol & w & w \\
\hline $\mathrm{H}_{2} \mathrm{~S}$ (SIM) & w & w & Dulcitol & + & + \\
\hline Hemolysis & - & - & Mannitol & $+w$ & + \\
\hline Neutral red reduction & $\mathbf{w}-$ & $\mathbf{w}$ & Sorbitol & $+w$ & + \\
\hline Acetylmethylcarbinol & $-w$ & - & Inositol & + & + \\
\hline Gas from: & & & Erythritol & - & - \\
\hline PYFG & - & - & Esculin & w & w \\
\hline PYF & - & - & Salicin & + & + \\
\hline $\mathrm{NH}_{3}$ & $-w$ & $\mathbf{w}$ & Amygdalin & + & + \\
\hline Litmus milk: & & & $\alpha$-Methylglucoside & + & + \\
\hline Acid & + & + & $\alpha$-Methylmannoside & + & + \\
\hline Curd & + & + & Starch hydrolysis & - & - \\
\hline \multirow{2}{*}{ Digestion } & $-\mathbf{w}$ & $\mathbf{w}$ & Esculin hydrolysis & + & + \\
\hline & & & Orotic acid hydrolysis & - & - \\
\hline
\end{tabular}

${ }^{a}$ Symbols: + , reaction positive for $>95 \%$ of strains or final $\mathrm{pH} 5.5$ or lower; - , reaction negative for $>95 \%$ of strains or final $\mathrm{pH}$ of $>6.0$; $\mathrm{w}$, reaction weak for $>95 \%$ of strains or final $\mathrm{pH}$ of 5.6 to 6.0 ; v, reaction variable within the strains or in a strain; +-, -w, etc., first reaction most frequent, 10 to $40 \%$ of strains had second reaction. Spore locations: C, central, S, subterminal. First location is most frequent, second is less frequent. Two different locations were usually observed in a strain. Products: ++ , major product; $(+)$, moderate product. Formic acid could not be detected by the method used.

${ }^{b}$ Range of the values of four strains.

No gas was formed from glucose. Gelatin was not liquefied. Indole was not produced. Hydrogen sulfide was weakly produced. Nitrate was not reduced to nitrite. Acid and curd were produced in litmus milk with occasional weak digestion. Lecithinase was not produced on egg yolk agar. Tributyrin was not hydrolyzed. Catalase, urease, threonine deaminase, and glutamic acid decarboxylase were not produced. Lactate was not converted to propionic acid.

Succinic acid was produced as a major product in PYFG broth with moderate amounts of 
TABLE 2. Characteristics that differentiate $C$. coccoides from other species with high $G+C$ contents in the genus Clostridium ${ }^{a}$

\begin{tabular}{|c|c|c|c|c|c|c|c|}
\hline Clostridium species & Product $^{b}$ & Maltose & Inositol & $\begin{array}{c}\text { Starch hydrol- } \\
\text { ysis }\end{array}$ & Indole & $\begin{array}{l}\text { Nitrate re- } \\
\text { duction }\end{array}$ & Gas \\
\hline C. coccoides & $\mathrm{Sa}$ & + & + & - & - & - & - \\
\hline C. sphenoides & $\operatorname{Af2}(1 \mathrm{~s})$ & + & $\mathbf{v}$ & $\mathbf{v}$ & + & $\mathbf{v}$ & + \\
\hline C. oroticum & AF2(1s) & + & $\mathrm{v}$ & - & - & + & + \\
\hline B. clostridiiformis ${ }^{c}$ & $\operatorname{Af}(21 s)$ & $\mathrm{v}$ & - & $\mathbf{v}$ & $\mathrm{v}$ & $\mathrm{v}$ & $\mathrm{v}$ \\
\hline C. indolis & A2(FSb1) & + & - & + & + & + & + \\
\hline C. innocuum & $\mathrm{ABL}(\mathrm{Fs})$ & - & - & - & - & & + \\
\hline C. barkeri & $\mathrm{BL}(4 \mathrm{ps})$ & - & - & - & - & - & + \\
\hline C. nexile & AF2(1s) & - & - & - & - & - & + \\
\hline
\end{tabular}

a The characteristics were determined by testing the strains used including the ATCC strains and by referring to the descriptions of the species by Smith and Hobbs (13) and/or Holdeman and Moore (2, 4). Symbols: + , reaction positive for $>95 \%$ of strains or final $\mathrm{pH}$ of 5.5 or lower; - , reaction negative for $>95 \%$ of strains or final $\mathrm{pH}$ of $>6.0 ; \mathrm{w}$, reaction weak for $>95 \%$ of strains or final $\mathrm{pH}$ of 5.6 to $6.0 ; \mathrm{v}$, reaction variable within the strains.

${ }^{b}$ Products: A, acetic acid; B, butyric acid; F, formic acid, L, lactic acid; P, propionic acid; S, succinic acid; 2, ethanol, 4, butanol. Capital letters, major products; small letters, minor products. Products in parentheses were not uniformly detected. 12).

This organism has been found to have spores and is considered to belong to the genus Clostridium $(3,6$,

acetic acid. Alcohols and propionic, isobutyric, butyric, isovaleric, valeric, and lactic acids were not produced. Formic acid could not be detected by the method used.

The $\mathrm{G}+\mathrm{C}$ contents of the DNAs were 44.3 , $45.1,42.9$, and $45.1 \mathrm{~mol} \%$ for CLC-1, CLC-4, CLC-8, and CLC-9, respectively.

A comparison of the cultural and biochemical characteristics, morphology, and fermentation products of these strains with those of the presently known species of the genus Clostridium indicates that these strains represent a new species, for which we propose the name Clostridium coccoides (coc.coi'des. Gr.n. coccus a berry; Gr.n. eidos shape; M.L.adj. coccoides berry-shaped). The type strain of $C$. coccoides is CLC-1 (= ATCC 29236 = NCTC 11035). This strain was isolated from the feces $\left(10^{6}\right.$ to $10^{9}$ cells per gram [wet weight]) of a mouse fed a lactose-rich diet.

Characteristics which qualify $C$. coccoides as a member of the genus Clostridium and differentiate it from other species with high $\mathrm{G}+\mathbf{C}$ content. $C$. coccoides is a member of the genus Clostridium because it is an obligately anaerobic, nonmotile, sporeforming, gram-positive, coccobacillary to rod-shaped organism. It is readily distinguished from other clostridia by its morphology as seen under the light microscope and/or by its $\mathrm{G}+\mathrm{C}$ content.

Table 2 shows the biochemical characteristics most useful in distinguishing $C$. coccoides from some other members of the genus Clostridium with relatively high $\mathrm{G}+\mathrm{C}$ contents, such as $C$. sphenoides (ATCC 19403, $41.0 \mathrm{~mol} \%$ ), C. oroticum (ATCC 13619, $43.7 \mathrm{~mol} \%$ ), B. clostridiifor- mis (ATCC 25537, $48.8 \mathrm{~mol} \%$ ), C. indolis (ATCC 25771, $44.7 \mathrm{~mol} \%$ ), C. innocuum (ATCC 14501, $44.5 \mathrm{~mol} \%)$, C. barkeri (45 mol\%) (5), and $C$. nexile (ATCC 27757, $40.5 \mathrm{~mol} \%$ ). The major product of fermentation by $C$. coccoides is succinic acid, usually with small amounts of acetic acid. It produces acid from maltose and inositol, does not produce indole and gas, does not hydrolyze starch, and does not reduce nitrate.

\section{REPRINT REQUESTS}

Address reprint requests to: Dr. Choji Kaneuchi, The Institute of Physical and Chemical Research, Wako-shi, Saitama, 351, Japan.

\section{LITERATURE CITED}

1. Caldwell, D. R., and M. P. Bryant. 1966. Medium without rumen fluid for nonselective enumeration and isolation of rumen bacteria. Appl. Microbiol. 14:794800.

2. Holdeman, L. V., and W. E. C. Moore (ed.). 1972. Anaerobe laboratory manual. Anaerobe Laboratory, Virginia Polytechnic Institute and State University, Blacksburg, Va.

3. Holdeman, L. V., and W. E. C. Moore. 1974. Bacteroidaceae, p. 384. In R. E. Buchanan and N. E. Gibbons (ed.), Bergey's manual of determinative bacteriology, 8th ed. The Williams and Wilkins Co., Baltimore.

4. Holdeman, L. V., and W. E. C. Moore. 1974, New genus, Coprococcus, twelve new species, and emended descriptions of four previously described species of bacteria from human feces. Int. J. Syst. Bacteriol. 24:260-277.

5. Johnson, J. L., and B. S. Francis. 1975. Taxonomy of the clostridia: ribosomal ribonucleic acid homologies among the species. J. Gen. Microbiol. 88:229-244.

6. Kaneuchi, C., K. Watanabe, A. Terada, Y. Benno, and T. Mitsuoka. 1976. Taxonomic study of Bacteroides clostridiiformis subsp. clostridiiformis (Burri and Ankersmit) Holdeman and Moore and related orga- 
nisms: proposal of Clostridium clostridiiforme (Burri and Andersmit) comb. nov. and Clostridium symbiosum (Stevens) comb. nov. Int. J. Syst. Bacteriol. 26:195-204.

7. Marmur, J. 1961. A procedure for the isolation of deoxyribonucleic acid from microorganisms. J. Mol. Biol. 3:208-218.

8. Marmur, J., and P. Doty. 1962. Determination of the base composition of deoxyribonucleic acid from its thermal denaturation temperature. J. Mol. Biol. 5:109-118.

9. Mitsuoka, T., Y. Morishita, A. Terada, and S. Yamamoto. 1969. A simple method ("plate-in-bottle method") for the cultivation of fastidious anaerobes. Jpn. J. Microbiol. 13:383-385.

10. Mitsuoka, T., T. Sega, and S. Yamamoto. 1965. Eine verbesserte Methodik der qualitativen und quantitativen Analyse der Darmflora von Menschen und
Tieren. Zentralbl. Bakteriol. Parasitenkd. Infektionskr. Hyg. Abt. 1 Orig. 195:455-469.

11. Parker, C. A. 1955 . Anaerobiosis with iron wool. Aust. J. Exp. Biol. Med. Sci. 33:33-38.

12. Reinhold, L., E. M. Barnes, and H. Beerens. 1967. Identification de Ristella biacutus (Prévot 1967) (ex Fusiformis biacutus, Prévot) avec Clostridium microsporum (Spray 1947). Bull. Off. Int. Epizoot. 67:1231-1237.

13. Smith, L. DS., and G. Hobbs. 1974. Clostridium Prazmowski, p. 551. In R. E. Buchanan, and N. E. Gibbons (ed.), Bergey's manual of determinative bacteriology, 8th ed. The Williams and Wilkins Co., Baltimore, Md.

14. Wachsman, J. T., and H. A. Barker. 1954. Characterization of an orotic acid fermenting bacterium, Zymobacterium oroticum, nov. gen., nov. spec. J. Bacteriol. 68:400-404. 